\title{
Preliminary Phytochemical Analysis of Pentapetes phoenicea L.
}

\author{
Yawalikar N., Bhowal M., Rudra J. \\ Department of Botany, Hislop College, Nagpur
}

\begin{abstract}
The present study was undertaken to study the phytochemicals present in Pentapetes phoenicea from the family Sterculiaceae. In nature the plant grows in moist soil. It can also be grown under the shade of trees as well as in open sunny areas. For preliminary phytochemical analysis different solvents like petroleum ether, chloroform, acetone, methanol and distilled water were used. It revealed the presence of alkaloids, flavonoids, saponins, steroids, phenolics, coumarins and triterpenoids in leaf, stem and root extracts.
\end{abstract}

Key words: Phytochemicals, Pentapetes phoenicea, alkaloids, flavonoids, phenolics.

\section{Introduction}

Phytoconstituents are the natural bioactive compounds found in plants. These phytoconstituents work with nutrients and fibres to form an integrated part of defence system against various diseases and stress conditions. Medicinal plants are of great importance to the health of individuals and communities. The medicinal value of these plants lies in some chemical substances that produce a definite physiological action on the human body. The most important of these bioactive constituents of plants are alkaloids, tannins, flavonoids and phenolic compounds (Hill, 1952).

Pentapetes is native to a wide region of tropical South Asia from Shrilanka and India to northern Australia and the Philippines. It is naturalised and occurs almost throughout the drier parts of India, along roadsides, wastelands near habitaions, dumping grounds and swampy areas. The fruit of Pentapetes phoenicea causes constipation, heats the body, and is difficult to digest: removes 'kapha': cures fever, 'vata': and 'pitta' (Ayurveda). The root is employed as an emollient in Annam and in China.

\section{Plant material}

\section{Material And Methods}

The whole plant of Pentapetes phoenicea was collected from the field. The different parts of the plant namely: leaves, stem and root were removed from the whole plant and air dried separately at room temperature. The dried parts were ground to powder and stored in polythene bags at room temperature. Chemical tests were carried out on different extracts to identify the constituents as described by Das and Bhattacharjee (1970), Gibbs (1974), Harborne (1984), Chhabra et al. (1984), Treases and Evans (1985), Daniel (1991), David (2000), Kokate et al. (2004).

Preparation of extract: - For preliminary phytochemical analysis, $15 \mathrm{gm}$ of the powdered plant material was taken in thimble of Whatman filter paper No. 1 and sohxelated with petroleum ether for about 12-16 hours. The petroleum ether extract (1a) was distilled off and the residue (1b) was dried overnight. The petroleum extract (1a) was tested for the presence of alkaloids, carotenoids, coumarins, flavonoids, steroids, phenolics and triterprnoids. The residue (1b) was Sohxelated with chloroform until complete decolourization takes place. The chloroform extract was collected and the residue (2b) was kept overnight for drying. This chloroform extract (2a) was tested for the presence of alkaloids, coumarins, flavonoids, steroids, phenolics and triterprnoids. The residue (2b) was Sohxelated with acetone for 4 - 5 hours and the acetone extract (3a) was collected. The residue (3b) was kept overnight. The acetone extract was tested for the presence of alkaloids, coumarins, flavonoids, steroids, phenolics and triterprnoids. The residue (3b) was Sohxelated with methanol for $10-12$ hours. The methanol extract (4a) was collected and the residue (4b) was dried till next day. The methanol extract (4a) was tested for the presence of alkaloids, anthocyanins, anthocynidins, anthracene glycosides, cardiac glycosides, coumarins, flavonoids, steroids phenolics, tannins and triterpenoids. The residue (4b) was finally Sohxelated with distil water for about $10-12$ hour. The water extract (5a) was tested for the presence of alkaloid, anthocyanins, anthocynidins, anthracene glycosides, carbohydrates, coumarines, flavonoids, steroids, phenolics, tannins, saponins, triterpenoids, gums and mucilage. The residue (5b) was discarded.

Alkaloids: All 5 extracts (1a, 2a, 3a, 4a, and 5a) were tested for the presence of alkaloids with Mayer's, Dragendorff's and Wagner's reagent. $2 \mathrm{ml}$ of each extract was taken separately in $5 \mathrm{ml}$ of $1.5 \% \mathrm{v} / \mathrm{v}$ aqueous $\mathrm{HCl}$ and filtered. The resulting acidic solution was divided into 4 parts. Three parts were tested with Mayer's, Dragendorff's and Wagner's reagent and the fourth part served as blank. A faint turbidity, light opalescence or 
yellowish white precipitate on addition of Mayer's reagent was the positive test for alkaloids Development of orange precipitate on addition of Dragendorf's reagent is a positive test for alkaloids.

Anthocyanins and Anthocynidins: The methanol and water extracts (4a and 5a) were tested for the presence of anthocyanins and anthocynidins. Red colour in acidic aqueous solution of extracts at $\mathrm{pH} 3-4$ indicated the presence of anthocyanins and change of colour with $\mathrm{pH}$ modification $(\mathrm{pH} 8-9)$ indicated the presence of anthocyanidins.

Anthracene Glycosides: Anthracene glycosides were screened in methanol and water extracts (4a and 5a). Residue of $4 \mathrm{a}$ and $5 \mathrm{a}$ mixed with $5 \mathrm{ml}$ ethanol. These ethereal solutions of extracts were treated with $25 \%$ ammonium hydroxide. The development of red colour indicated the presence of anthracene glycosides.

Coumarins: All the extracts (1a, 2a, 3a, 4a and 5a) were dried and the residues were dissolved in petroleum ether. The resulting extracts were taken in test tubes covered with filter paper moistened with dilute sodium hydroxide solution. They were then placed in boiling water bath for 20 to 30 minutes. The filter paper was removed and test tube was exposed to U.V.light. A yellowish fluorescence shows the presence of coumarins.

Flavonoids: All the extracts were dried and the residue was dissolved in ethanol. On addition of magnesium powder and conc. $\mathrm{HCl}$, the development of yellow or red colour indicated the presence of Flavonoids.

Steroids: All 5 extracts (1a, 2a, 3a, 4a and 5a) were screened for the presence of steroids. The test was carried out by Salkowski reaction and Libermann-Burchard reaction (Maiti, 1968).

Salkowski reaction- A few $\mathrm{mg}$ of the residue was taken in $2 \mathrm{ml}$ of the chloroform. To this, $2 \mathrm{ml}$ of conc. $\mathrm{H}_{2} \mathrm{SO}_{4}$ was added by the side of the test tube. The test tube was shaken for few minutes. Red colour developed in chloroform layer and lower layer of acid gave greenish yellow fluorescence. This colorization and fluroscence is due to presence of steroids.

Libermann-Burchard reaction- A few mg of the residue was dissolved in chloroform. To this few $\mathrm{ml}$ of acetic anhydride and two drops of conc. $\mathrm{H}_{2} \mathrm{SO}_{4}$ were added from the side of the test tube. The transient greenish colour indicates the presence of steroids.

Saponins: Saponins were tested with water extracts (Cambie et al. 1961 and Harborne, 1998). $2 \mathrm{ml}$ of the extract (5a) was shaken vigorously for $10 \mathrm{sec}$. and allowed to stand. The formation of persistent honeycomb like froth is the positive test for the presence of saponins.

Phenolics: The dried residue of each extract (1a, 2a, 3a, 4a and 5a) was dissolved in methanol. This methanolic extract was tested for the presence of phenolics by the method given by Harborne (1998). A few drops of $1 \%$ alcoholic ferric chloride solution were added to the extract. The appearance of intense green, purple, blue or black colouration indicated the presence of phenolic compound in the sample.

Triterpenoids: All 5 extracts (1a, 2a, 3a, 4a and 5a) were tested for the presence of triterpenoids by Libermann Burchard reaction. A few $\mathrm{mg}$ of the residue was dissolved in chloroform. To this was added few $\mathrm{ml}$ of acetic anhydride and two drops of conc. $\mathrm{H}_{2} \mathrm{SO}_{4}$ from the side of the test tube. The red or violet colour indicated the presence of triterpenoids.

Tannins: Presence of tannins was tested in methanol and water extracts (4a and $5 \mathrm{a}$ ). $0.5 \mathrm{ml}$ of extract was diluted with $1 \mathrm{ml}$ of water and 2-3 drops of dilute ferric chloride solution. The development of blue or green black colour indicated the presence of tannins.

Cardiac glycosides: The methanol extract (4a) was tested for the presence of cardiac glycosides by KellerKiliani tests. $1 \mathrm{ml}$ of glacial acetic acid was added to $2 \mathrm{ml}$ of the extract in a test tube. In this mixture, few $\mathrm{ml}$ of ferric chloride followed by two drops of conc. $\mathrm{H}_{2} \mathrm{SO}_{4}$ were added. Green-blue colour indicated the presence of cardiac glycosides.

Carbohydrates: Water extract (5a) was tested for the presence of sugars by Molish's tests. Few ml of extract was placed in a test tube containing $0.5 \mathrm{ml}$ of water and mixed with 2 drops of $10 \%$ solution of 1-napthol in alcohol. $1 \mathrm{ml}$ of conc. $\mathrm{H}_{2} \mathrm{SO}_{4}$ was added from the side of the test tube. Appearance of red-violet ring at the junction of two layers indicated the presence of carbohydrates.

Gums and mucilage: To $5 \mathrm{ml}$ of water extract (5a), $15 \mathrm{ml}$ of alcohol was added and stirred; formation of mucilaginous texture of precipitation was the test of gums and mucilage.

\section{Results}

Table 1: Distribution of various phytochemicals in different plant parts

\begin{tabular}{|l|l|l|l|l|}
\hline Solvent & Species & Pentapetes phoenicea & Root \\
\hline \multirow{4}{*}{ Petroleum ether } & Compounds & Leaves & Stem & Root \\
\cline { 2 - 5 } & Alkaloids & + & - & - \\
\cline { 2 - 5 } & Carotenoids & + & + & - \\
\cline { 2 - 5 } & Coumarins & + & + & + \\
\cline { 2 - 5 } & Flavonoids & - & - & - \\
\cline { 2 - 5 } & Steroids & + & + & + \\
\cline { 2 - 5 } & Phenolics & + & + & + \\
\cline { 2 - 5 } & Triterpenoids & - & - & - \\
\hline Chloroform & Alkaloids & + & + & + \\
\hline
\end{tabular}




\begin{tabular}{|c|c|c|c|c|}
\hline & Coumarins & + & + & + \\
\hline & Flavonoids & - & - & - \\
\hline & Steroids & + & + & + \\
\hline & Phenolics & + & + & + \\
\hline & Triterpenoids & - & - & - \\
\hline \multirow[t]{6}{*}{ Acetone } & Alkaloids & + & - & - \\
\hline & Coumarins & + & + & + \\
\hline & Flavonoids & - & + & + \\
\hline & Steroids & + & + & + \\
\hline & Phenolics & + & + & + \\
\hline & Triterpenoids & - & + & + \\
\hline \multirow[t]{11}{*}{ Methanol } & Alkaloids & + & - & - \\
\hline & Anthocyanins & - & - & - \\
\hline & Anthocynidins & - & + & + \\
\hline & Anthracene glycosides & - & - & - \\
\hline & Cardiac glycosides & - & - & - \\
\hline & Coumarins & + & + & + \\
\hline & Flavonoids & + & + & + \\
\hline & Steroids & + & + & + \\
\hline & Phenolics & + & + & + \\
\hline & Tannins & + & + & + \\
\hline & Triterpenoids & - & + & + \\
\hline \multirow[t]{13}{*}{ Distilled water } & Alkaloids & - & - & - \\
\hline & Anthocyanins & - & + & + \\
\hline & Anthocynidins & + & - & - \\
\hline & Anthracene glycosides & - & - & - \\
\hline & Carbohydrates & + & + & + \\
\hline & Coumarins & + & + & + \\
\hline & Flavonoids & - & - & - \\
\hline & Steroids & + & + & + \\
\hline & Phenolics & + & + & + \\
\hline & Tannins & + & - & - \\
\hline & Saponins & + & + & + \\
\hline & Triterpenoids & + & + & + \\
\hline & Gums \& mucilage & - & - & - \\
\hline
\end{tabular}

Pentapetes phoenicea is rich in phytochemical constituents as shown in Table 1. The phytochemical analysis shows the presence of alkaloids in chloroform extract of leaf, stem and root. Also the petroleum ether, acetone and methanol extracts of leaf show the presence of alkaloids. Coumarins, steroids and phenolics are present in all the five extracts. Methanolic extract shows the presence of flavonoids and distilled water extract shows the presence of saponins. Triterpenoids are present in all the extracts except petroleum ether and chloroform. Anthracene glycosides and cardiac glycosides are absent in all the plant parts.

\section{Discussion}

The present investigation was carried out to study the presence of medicinally active phytochemicals in leaves, stem and root of Pentapetes phoenicea. Different types of solvent plays an important role in the extraction of different phytochemicals. In the present investigation alkaloids are found to be better extracted by chloroform while alkaloids are absent in distilled water extract.

Flavonoids are also one of the largest classes of plant phenol; perform very different functions in plant system including pigmentation and defence. Methanolic extract of this plant showed the presence of flavonoids in all the parts. Extract of leaf and stem of Waltheria indica (Sterculiaceae) showed the presence of flavonoids (Zailani, 2010). Sonibare (2009) investigated the phytochemical screening in the ethanolic extract of the leaf sample of four Cola species (Sterculiaceae) and showed the presence of alkaloids, saponins and tannins.

Plants produce a large variety of secondary products that contain a phenol group. They could be an important part of the plants defense system against pests, diseases including root parasitic nematodes (Wuyts et al., 2006). In the present study, phenolics were detected in all the parts of this plant. Phenolic compounds were detected from the Theobroma cacao hulls (Arlorio et al., 2005).

Saponins are also present in all the parts of this plant. Coumarins are simple phenolic compounds, widespread in vascular plants and appear to function in different capacities in various plant defense mechanisms against herbivores and fungi. The present investigation also shows the presence of coumarins.

\section{Conclusion:}

The present investigation was carried out to study the presence of medicinally active phytochemicals like alkaloids, flavonoids, phenols, saponins and coumarins in leaves, stem and root of Pentapetes phoenicea. These phytochemicals play important role in various plant defense mechanisms against herbivores, fungi and 
bacteria. In future, these secondary metabolites can be extracted from this plant and may be used as medicine. Studies on quantitave analysis, antibacterial and antioxidant activity can also be conducted for future references.

\section{Acknowledgement}

We are thankful to the Principal, Hislop College, Nagpur, (Ms.) Dipti Christian, for availing all facilities required for this research work.

\section{References}

[1]. Arlario M, Coisson JD, Travaglia F, Varsaldi F, (2005) Antioxidant and biological activity of phenolic pigments from Theobroma cacao hulls extracted with supercritical $\mathrm{CO}_{2}$. Food Research Int., 1009-1014.

[2]. Cambie RC, Cain BF and Laroche (1961) A New Zealand phytochemical survey (III) ferns and fern allies. New Zealand J. Sci. 4: 707-714.

[3]. Chhabra SC, Viso FC and Mshiv EN (1984) Phytochemical screening of Tanzanian medicinal plants. Int. J. Ethaopharmacol. 11: 157-179.

[4]. Daniel M (1991) Methods in Plant Chemistry and Economic Botany, Kalyani Publishers, New Delhi, India

[5]. Das AK and Bhattacharjee AK (1970) A systemic approach to phytochemical screening Tropical Science, $12: 54-58$.

[6]. David PJ (2000) Phytochemistry of medicinal plants. Phytochemistry 56: 237-248.

[7]. Gibbs RD (1974) Chemotaxonomy of Flowering Plants I-IV Montreal and London, McGill Queens University Press.

[8]. Harborne JB (1984) Phytochemical methods, London. Chapman and Hall, Ltd. 100-101.

[9]. Harborne JB (1998) Phytochemical Methods- A guide to modern Techniques of plant analysis. Chapman and hall, London, U.K.

[10]. Hill AF (1952) Economic Botany. A textbook of useful plants and plant products. $2^{\text {nd }}$ edition. McGraw-Hill Book Company Inc. New York.

[11]. Kokate CK, Purohit AP and Gokhale SB (2004) Practical Pharmacognasy, ed. (2), Vallabh Prakashan, Delhi, India.

[12]. Maiti PC (1968) Phytochemical screening Bull Bot Surv. Ind 10 (2): $111-122$.

[13]. Sonibare MA, Soladaye MO, Esan OO and Sonibare OO (2009) Phytochemical and antimicrobial studies of four species of Cola Schott \& Endl.(Sterculiaceae). Afr. J. Traditional, Complementary and Alternative Medicines. 6 (4): 518 - 525.

[14]. Trease GE, Evans WC (1985) Text Book of Pharmacognosy, $12^{\text {th }}$ edition, Tindall Publication, Great Britain.

[15]. Wuyts N, De waele D, Swennen R (2006) Extraction and partial characterization of polyphenol oxidase from banana (Musa acuminate grandr naine) roots. Plant Physiology and Biochemistry, 44: 308-314.

[16]. Zailani, Hauwa A, Jada and Mahmud (2010) Antimicrobial activity of Waltheria indica, J. American Science, 6(12): 1591 -1594. 